- Облік і оподаткування

УДК 657.631.8:336.02

JEL Classification: E62, F65, G28

КАЛІНЕСКУ Т. В. ${ }^{1}$, ПЕРЕПЕЛИЦЯ Ю. Г. ${ }^{2}$

\title{
УДОСКОНАЛЕННЯ ОБЛІКУ ТА ОПОДАТКУВАННЯ ФІНАНСОВО-КРЕДИТНИХ УСТАНОВ
}

DOI: $10.32620 /$ cher.2021.2.04

Постановка проблеми. Питання удосконалення податкового обліку та оподаткування банківських установ є особливо актуальним і важливість фінансово-кредитних організацій невпинно зростає, оскільки саме банк виступає сполучною ланкою між населенням та підприємствами, забезпечуючи їх сталу, ефективну роботу. Тому існує потреба у пошуку нових стимулів й мотивів щодо реформування податкової політики у банківській сфері з метою збалансування податкового навантаження на всі сфери діяльності національної економіки, підвищення репутації та активності банківського сектору. Мета дослідження спрямована на розробку практичних рекомендацій щодо застосування дієвих податкових заходів для удосконалення процесу оподаткування фінансово-кредитних установ та їх податкового обліку. Методологічною основою дослідження стали законодавчі та нормативноправові акти, сучасні науково - прикладні дослідження в банківській сфері. В проведених дослідженнях використані методи діалектики, способи і принципи наукового пізнання, інструменти економічного аналізу для обгрунтування пропозицій щодо зміни оподаткування банківських установ. Основною гіпотезою дослідження стало припущення щодо можливості оптимізації податкової політики та удосконалення податкового обліку фінансово-кредитних установ шляхом введення податку на комісійні доходи. Виклад основного матеріалу. У статті досліджено основні проблемні аспекти оподаткування фінансово-кредитних установ, розроблено шляхи оптимізації податкової політики банків та удосконалення процесу податкового обліку, запропоновані нововведення в оподаткуванні, банків, обгрунтована необхідність їх реалізації задля ефективного розвитку банківського сектору та стимулювання їх діяльності. Оригінальність та практична значимість підтверджується запропонованими в прибутковому оподаткуванні банківських операцій, що дозволить оптимізувати процеси оподаткування фінансово-кредитних установ. Висновки та перспективи подальших досліджень. Доведено, що оптимізація податкової політики за допомогою введення податку на комісійні доходи може бути реалізована, бо відповідає усім викликам, що відповідають сучасним етапу розвитку національної економіки та податковій політиці, що проводиться у зарубіжних європейських країнах по відношенню до банківських установ. Подальші дослідження будуть спрямовані на аналіз чинників, що можуть впливати на реформування та удосконалення обліку й оподаткування фінансовокредитних установ.

Ключові слова:

податкова політика, банківський сектор, комісійні доходи, оптимізація оподаткування, удосконалення податкового обліку.

${ }^{1}$ Калінеску Тетяна Василівна, д-р екон. наук, професор, завідувач кафедри фінансів, обліку і оподаткування, Національний аерокосмічний університет ім. М. Є. Жуковського «Харківський авіаційний інститут», м. Харків, Україна.

Calinescu Tetyana, Doctor of Economic Sciences, Professor, Head of Finance, Accounting and Taxation Department, National Aerospace University «Kharkiv Aviation Institute», Kharkiv, Ukraine.

ORCID ID: 0000-0003-4919-5788

e-mail: tetyana.calinescu@gmail.com

${ }^{2}$ Перепелиця Юліанна Геннадіївна, студентка спеціальності 071 «Облік і оподаткування», Національний аерокосмічний університет ім. М. С. Жуковського «Харківський авіаційний інститут», м. Харків, Україна.

Perepelytsia Yuliana, student of 071 Accounting and Taxation Speciality, National Aerospace University «Kharkiv Aviation Institute», Kharkiv, Ukraine.

ORCID ID: 0000-0001-6684-161X

e-mail: y.g.perepelitsya @student.khai.edu 


\section{IMPROVEMENT OF ACCOUNTING AND TAXATION THE FINANCIAL AND CREDIT ESTABLISHMENTS}

Formulation of the problem. A question of improvement the fiscal accounting and taxation of bank institutions is especially actual and importance of financial and credit organizations grows, because a bank comes forward as an interlink between a population and enterprises, providing its stability, effective activity. Therefore, there is a requirement in the search of new stimuli and reasons in relation to reformation of tax policy in a bank sphere with the aim of balanced of the tax loading on all spheres of national economy activity, increase of reputation and activity bank to the sector. A research aim is sent to development of practical recommendations in relation to application of effective tax measures for the improvement the process of taxation the financial and credit establishments and its fiscal accounting. Methodological basis of research is becoming legislative and normatively-legal acts modern scientifically - applied researches in a bank sphere. In the conducted researches are used methods of dialectics, methodic and principles of scientific cognition, instruments of economic analysis for the ground of suggestions in relation to the change of taxation the bank institutions. The basic hypothesis of research is becoming supposition in relation to possibility of optimization the tax policy and improvement of the fiscal accounting the financial and credit establishments by introduction of tax on commission profits. Exposition of basic material. In the article are investigate the basic problem aspects of taxation the financial and credit establishments, the ways of optimization the tax policy of banks and improvement of process the fiscal accounting, offered innovations in taxation of banks, reasonable necessity of its realization for the sake of effective development bank to the sector and stimulation of its activity. Originality and practical meaningfulness are confirmed by offered in profitable taxation of bank transactions that will allow optimizing the processes of taxation the financial and credit establishments. Conclusions and prospects of further researches. It is well-proven that optimization of tax policy by means of introduction of tax on commission profits can be realized, because answers all calls, that answer modern to the stage of development the national economy and tax policy that is conducted in the foreign European countries in relation to bank institutions. Further researches will be sent to the analysis of factors that can influence on reformation and improvement of accounting and taxation the financial and credit establishments.

Key words:

tax policy, bank sector, commission profits, optimization of taxation, improvement of the fiscal accounting.

\section{СОВЕРШЕНСТВОВАНИЕ УЧЕТА И НАЛОГООБЛОЖЕНИЯ ФИНАНСОВО- КРЕДИТНЫХ УЧРЕЖДЕНИЙ}

Постановка проблемы. Вопросы совершенствования налогового учета и налогообложения банковских учреждений сегодня особенно актуальны и их значимость для банковских организаций постоянно растет, так как банки выступают связующим звеном между населением и предприятиями, обеспечивая постоянную стабильную эффективную деятельность. Отсюда вытекает потребность в поиске новых стимулов и мотивов относительно реформ в налоговой политике банковской сферы с целью сбалансирования налоговой нагрузки всех сферах деятельности национальной экономики, увеличения репутации банков и активизации деятельности всех секторов. Целью исследования является разработка практических рекомендаций относительно применения эффективных налоговых мероприятий по совершенствованию процесса налогообложения финансово-кредитных учреждений и их налогового учета. Методологической основой исследования стали современные законодательные и нормативные акты, применяемые для исследования банковской сферы. В проведенных исследованиях использованы методы диалектики, методики и принципы научного познания, инструменты экономического анализа, предложения относительно изменения налогообложения банковских учреждений. Основной гипотезой исследования стало предположение относительно возможной оптимизации налоговой политики и совершенствования налогового учета финансово-кредитных учреждений, введение налога на комиссионные доходы. Изложение основного материала. В статье исследуются основные проблемные аспекты налогообложения финансово-кредитных учреждений, пути оптимизации налоговой политики банков и совершенствование процессов налогового учета, предложены нововведения в налогообложении банков, обоснована потребность в их реализации для эффективного развития банковского сектора и стимулированию его деятельности. Оригинальность u практическую значимость подтверждают предложенное подоходное налогообложение банковских операций, что позволит оптимизировать процессы налогообложения финансово-кредитных 
учреждений. Bыводы и перспективы дальнейших исследований. Доведено, что оптимизация налоговой политики посредством введения налога на комиссионные доходы может быть реализована, потому что отвечает всем вызовам, которые отвечают современным этапам развития национальной экономики и налоговой политики, которая проводится в зарубежных Европейских странах относительно банковских учреждений. Дальнейшие исследования будут сосредоточены на анализ факторов, которые могут повлиять на реформирование и совершенствование учета и налогообложение финансово-кредитных учреждений.

Ключевые слова:

налоговая политика, банковский сектор, комиссионные доходы, оптимизация налогообложения, совершенствование налогового учета.

Постановка проблеми. На сьогодні податковий облік та оподаткування банківських установ в Україні здійснюються згідно затверджених на законодавчому рівні норм, принципів та правил регулювання основних бізнес-процесів банків $[1,2]$. Сучасні податкові відносини між державою та банками наразі $є$ неефективні, а державне податкове регулювання діяльності фінансово-кредитних установ більш стримує банківську активність, ніж сприяє оптимізації їх оподаткування і удосконаленню процесів обліку податків. Більша частина банківських операцій наразі не обкладається одним iз найбільш бюджетоутворюючих податків, - податком на додану вартість (ПДВ), а загалом оподатковуються прибутковими податками, що, знижує податкову активність та зобов'язання банківського сектору економіки. Схожа ситуація відбувається також iз податковим обліком фінансовокредитних установ, що мають своєчасно сплачувати та заповнювати різні форми оперативної й податкової звітності. Тому виникає потреба у пошуку нових стимулів й мотивів щодо реформування податкової політики у банківській сфері з метою збалансування податкового навантаження на всі сфери діяльності національної економіки, підвищення репутації та активності банківського сектору.

Аналіз останніх досліджень і публікацій. Дослідженню проблемних питань щодо обліку і оподаткування фінансовокредитних установ присвячено праці учених таких як: О. Д. Данилов, Д. С Денисенко [3], I. І. Д'яконова [4], Л. А. Клюско [5, 6], А. Т. Ковальчук [7], Н. Й. Реверчук [8], О.Г. Сербина [9], А. В. Сурженко [10] та інших. Більшість наукових розробок розк- ривають питання податкового обліку та оподаткування без урахування змін, що постійно відбуваються у банківській системі України, внаслідок глобальних викликів. Важливе місце у даних працях займають законодавчі зміни мають відбутися у банківській системі. Тому пошук можливих шляхів удосконалення оподаткування фінансово-кредитних установ $є$ багатогранним питанням, що потребує подальшого дослідження та ефективного розв'язання відповідності світовим трансформаціям у суспільстві.

Звідки метою статті $\epsilon$ розробка дієвих заходів щодо удосконалення обліку i оподаткування фінансово-кредитних установ відповідно сучасних вимог i задля сприяння подальшого економічному розвитку банківської системи.

Виклад основного матеріалу дослідження. Облік та оподаткування банківських операцій в Україні сьогодні досить часто порівнюється із станом в зарубіжних банках. для створення ефективної системи оподаткування та організації досканалого обліку і аудиту банківських операцій [10]. Євроінтеграційні процеси відіграють важливу роль у розвитку банківської системи України [11], в том числі для аналізу й прийняття коректних рішень щодо трансформації податкової політики України відповідно до політики СС (рисунок 1).

Треба зазначити, що вітчизняні банки хоч і мають меншу кількість податків, проте обкладаються значною кількістю зборів, що стримує розвиток банківської системи. Тому до негативних рис оподаткування та податкового обліку банків слід віднести:

збори, що не сприяють наповненню державного бюджету країни; 


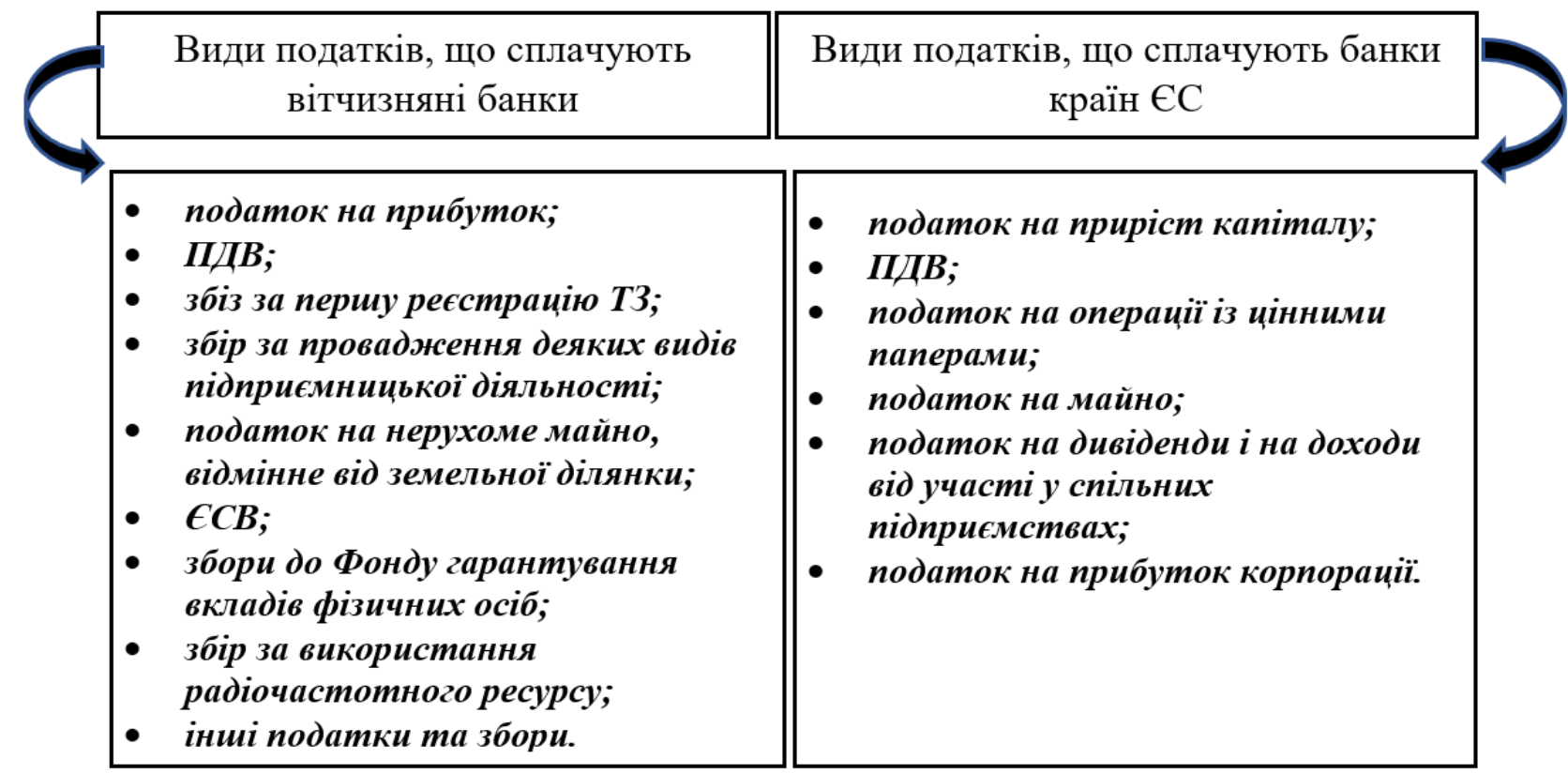

Рисунок 1 - Склад податків, що сплачуються фінансово-кредитними установами в Україні та ЄС Джерело: розроблено авторами на підставі [11]

процес розрахунку та сплати податків фінансово-кредитними установами є занадто трудомістким;

надмірна кількість заповнення різної звітності та подача ї у визначені терміни.

Усі ці обов'язкові податкової активності та надмірне обкладання фінансовокредитних установ зборами є раціональним як з точки зору їх обліку, так із погляду мотивування і стимулювання щодо повної їх сплати. Що стосується податкового обліку нарахування різних зборів, а саме їх кількість, можуть знизити податкову репутацію банківських установ та переводити ці процес у тіньову економіку. Тому у якості удосконалення обліку та оподаткування банківських операцій рекомендовано впровадити більш ефективний податок, що за своєю сутністю може замінити усі існуючи банківські збори. Цей податок буде сприяти збалансуванню фінансових взаємовідносин між державою та банками, мотивуватиме розвиток банківської системи, забезпечить якість надання банківських послуг, банкротство фінансово-кредитних установ, зниження податкового навантаження як на населення, так і на банки.

На даний момент рівень податкового навантаження, що впливає на банківські установи знаходиться у межах 20-40\% [3]. Для розрахунку реального показника податкового навантаження на банківський сек- тор за 2015-2020 роки, можна скористуватися формулою:

$$
\Pi H=(B П / Ф Р) \times 100 \%
$$

де ПН - податкове навантаження 3 податку на прибуток;

ВП - витрати з податку на прибуток;

ФР - фінансовий результат.

Проведених розрахунки показують, що банківський сектор має досить низький рівень податкового навантаження. А значить сучасна податкова політика, що проводиться по відношенню фінансовокредитних установ $\epsilon$ не ефективною, не стимулюючою та не використовує податковий потенціал банківських установ у повному обсязі. За 2015 - 2020 роки податкове навантаження досягло лише значення 22,4\% у 2018 році, а за всі інші періоди, податкове навантаження майже, вдвічі - втричі нижче, що свідчить про нестабільність функціонування сучасної банківської системи та проведення податкової політики.

Метою діяльності будь-якої фінансово-кредитної, банківської установи як і комерційних підприємств чи організацій, $\epsilon$ отримання прибутку, тому для раціонального формування бази прибуткового оподаткування слід переглянути структуру доходів та витрат банківських установ. 
Таблиця 1: Податкове навантаження банківських установ України за 2015-2020 pр., (млрд. грн.)

\begin{tabular}{|l|c|c|c|c|c|c|c|}
\hline \multicolumn{1}{|c|}{ Показник } & \multicolumn{7}{|c|}{ Роки } \\
\cline { 2 - 8 } & 2015 & 2016 & 2017 & 2018 & 2019 & 2020 & І кв. 2021 \\
\hline $\begin{array}{l}\text { Податок на } \\
\text { прибуток }\end{array}$ & $-0,406$ & $-0,418$ & 3,681 & 5,057 & 4,769 & 3,811 & 1,208 \\
\hline $\begin{array}{l}\text { Фінансовий } \\
\text { результат (прибу- } \\
\text { ток/збиток) }\end{array}$ & $-66,600$ & $-159,388$ & $-26,491$ & 22,339 & 58,356 & 39,727 & 10,935 \\
\hline $\begin{array}{l}\text { Показник подат- } \\
\text { кового } \\
\text { навантаження }\end{array}$ & $0,6 \%$ & $0,26 \%$ & $-13,9 \%$ & $22,4 \%$ & $8,2 \%$ & $9,6 \%$ & $11 \%$ \\
\hline
\end{tabular}

Джерело: розроблено авторами на підставі $[12,13,14,15]$.

Рекомендовано розглядати у складі доходу банків основні процентні та непроцентні доходи. Як правило, процентні доходи становлять до $70 \%$ доходів банку [12, $13,14,15]$, в той час як комісійні - 30\%, ці складові доходів займають відчутний відсоток у доходах банків. Саме вони мають бути підгрунтям для визначення розміру податкового навантаження в банках.
Проведені розрахунки показали негативну динаміку змін процентних витрат банків та загальної суми витрат (таблиця 2). Величина комісійних витрат у середньому зростала на 1,5-2\% за рік, проте зростання витрат $€$ меншим за показник росту доходів і ця ситуація є стійкою.

Таблиця 2: Структура та динаміка доходів та витрат банківських установ за 2015-2020 pp.

\begin{tabular}{|c|c|c|c|c|c|c|c|}
\hline \multicolumn{4}{|c|}{$\begin{array}{c}\text { Доходи та динаміка їх змін за період } \\
\text { 2015-2020 pp. }\end{array}$} & \multicolumn{4}{|c|}{$\begin{array}{l}\text { Комісійні витрати та динаміка їх змін за } \\
\text { період 2015-2020 pp. }\end{array}$} \\
\hline Роки & $\begin{array}{l}\text { Види до- } \\
\text { ходів }\end{array}$ & $\begin{array}{c}\text { Абсолютні } \\
\text { значення } \\
\text { (млн, грн) }\end{array}$ & $\begin{array}{c}\text { Питома вага } \\
\text { в загальних } \\
\text { доходах, \% }\end{array}$ & Роки & $\begin{array}{l}\text { Структу- } \\
\text { ра витрат }\end{array}$ & $\begin{array}{c}\text { Абсолютні } \\
\text { значення } \\
\text { (млн, грн) }\end{array}$ & $\begin{array}{c}\text { Питома } \\
\text { вага в ви- } \\
\text { тратах, \% }\end{array}$ \\
\hline \multirow{2}{*}{2015} & $\begin{array}{l}\text { комісійні } \\
\text { доходи }\end{array}$ & 28414 & $14,3 \%$ & \multirow{2}{*}{2015} & $\begin{array}{l}\text { комісійні } \\
\text { витрати }\end{array}$ & 5846 & $2,2 \%$ \\
\hline & $\begin{array}{l}\text { процентні } \\
\text { доходи }\end{array}$ & 135145 & $67,8 \%$ & & $\begin{array}{l}\text { процентні } \\
\text { витрати }\end{array}$ & 96079 & $36,1 \%$ \\
\hline \multirow{2}{*}{2016} & $\begin{array}{l}\text { комісійні } \\
\text { доходи }\end{array}$ & 31362 & $16,4 \%$ & \multirow{2}{*}{2016} & $\begin{array}{l}\text { комісійні } \\
\text { витрати }\end{array}$ & 7182 & $2,05 \%$ \\
\hline & $\begin{array}{l}\text { процентні } \\
\text { доходи }\end{array}$ & 135807 & $71,2 \%$ & & $\begin{array}{l}\text { процентні } \\
\text { витрати }\end{array}$ & 91638 & $26,2 \%$ \\
\hline \multirow{2}{*}{2017} & $\begin{array}{l}\text { комісійні } \\
\text { доходи }\end{array}$ & 37138 & $20,8 \%$ & \multirow{2}{*}{2017} & $\begin{array}{l}\text { комісійні } \\
\text { витрати }\end{array}$ & 9650 & $4,7 \%$ \\
\hline & $\begin{array}{l}\text { процентні } \\
\text { доходи }\end{array}$ & 124009 & $69,6 \%$ & & $\begin{array}{l}\text { процентні } \\
\text { витрати }\end{array}$ & 70971 & $34,7 \%$ \\
\hline \multirow{2}{*}{2018} & $\begin{array}{l}\text { комісійні } \\
\text { доходи }\end{array}$ & 50969 & $24,9 \%$ & \multirow{2}{*}{2018} & $\begin{array}{l}\text { комісійні } \\
\text { витрати }\end{array}$ & 13159 & $7,2 \%$ \\
\hline & $\begin{array}{l}\text { процентні } \\
\text { доходи }\end{array}$ & 140803 & $68,8 \%$ & & $\begin{array}{l}\text { процентні } \\
\text { витрати }\end{array}$ & 67760 & $37,2 \%$ \\
\hline \multirow{2}{*}{2019} & $\begin{array}{l}\text { комісійні } \\
\text { доходи }\end{array}$ & 62057 & $25,5 \%$ & \multirow{2}{*}{2019} & $\begin{array}{l}\text { комісійні } \\
\text { витрати }\end{array}$ & 18096 & $9,8 \%$ \\
\hline & $\begin{array}{l}\text { процентні } \\
\text { доходи }\end{array}$ & 152954 & $62,9 \%$ & & $\begin{array}{l}\text { процентні } \\
\text { витрати }\end{array}$ & 74062 & $40,1 \%$ \\
\hline \multirow{2}{*}{2020} & $\begin{array}{l}\text { комісійні } \\
\text { доходи }\end{array}$ & 70640 & $28,2 \%$ & \multirow{2}{*}{2020} & $\begin{array}{l}\text { комісійні } \\
\text { витрати }\end{array}$ & 24132 & $11,5 \%$ \\
\hline & $\begin{array}{l}\text { процентні } \\
\text { доходи }\end{array}$ & 147743 & $59 \%$ & & $\begin{array}{l}\text { процентні } \\
\text { витрати }\end{array}$ & 62895 & $29,9 \%$ \\
\hline
\end{tabular}


Проведені дослідження структури доходів та витрат банківських установ довело доречність впровадженні податку для непроцентних доходів банківських установ. Більша частина банківських операцій не оподатковується податком на додану вартість, тому податок на непроцентні доходи - це, по суті, податок, який можна включати в ціну комісії. Цей податок можна прирівняти до податку на приріст капіталу, бо комісійні доходи вітчизняних банків стабільно зростають, що можна розцінювати як постійний приріст капіталу.

Результати дослідження показали необхідність оптимізації оподаткування і податкового обліку фінансово-кредитних установ. Одним із можливих шляхів удосконалення цього питання $\epsilon$ впровадження «комісійного податку», який може бути встановлений в діапазоні 10 - 20\% на комісійний доход, в залежності від територій, де знаходяться фінансово-кредитні установи. Впровадження цього податку з одного боку підвищить податкове навантаження на банківський сектор економіки, підвищить ефективність податкової політики та зробить і1і більш вмотивованою як для активізації розвитку банківського сектору економіки, так й для населення окремих територій щодо користування послугами банківських установ й виступить ефективний стимулятором з боку держави.

Запропоновані шляхи удосконалення оподаткування фінансово-кредитних установ, безумовно, сприяють розвитку сучасного стану фіскальної політики держави та здатні стимулювати банківські установи до успішного розвитку й запровадження різних банківських операцій.

Висновки та перспективи подальших досліджень. Таким чином, удосконалити сучасний стан обліку та оподаткування банківських установ можна за допомогою нових, ефективних комісійного податку. Впровадження певних податків потребує експертного та незалежного аудиторського дослідження, в тому числі всебічного аналізу, юридичної оцінки та обгрунтованості. Подальші дослідження будуть спрямовані на аналіз чинників, що можуть впливати на реформування та удосконален- ня обліку й оподаткування фінансовокредитних установ.

\section{Література}

1. «Засади стратегічного реформування державного банківського сектору (стратегічні принципи)» від 20 серпня 2020 року. [Електронний ресурс]. URL: https://www.oschadbank.ua/sites/default/files/fil es/documents-2020.

2. Закон України «Про внесення змін до статті 62 Закону України «Про банки і банківську діяльність» щодо забезпечення доступу центрального органу виконавчої влади, що реалізує державну податкову політику, до банківської таємниці» від 08.09.2020 p. № 4073. [Електронний ресурс]. URL: https://ips.ligazakon.net/document/GI03122A.

3. Данілов О. Д., Денисенко Д. Є. Тенденції оподаткування капіталу в Україні і світі. Бізнес Інформ. 2014. № 3. С. 295-300.

4. Д'яконова I. І., Мордань С. Ю. Дослідження оцінки рівня фінансової стабільності як складового елементу механізму державного регулювання банківської системи. Бізнес Інформ. 2015. № 1. С. 302-306.

5. Клюско Л. А. Грошово-кредитне регулювання в умовах макроекономічної нестабільності. Збірник наукових праць Університету державної фіскальної служби України. 2018. № 2. C. 107-119.

6. Клюско Л. А. Інновації у сфері банківського бізнесу. Збірник наукових праць Університету державної фіскальної служби України. 2019. № 2. С. 109-128.

7. Ковальчук А. Т. Фінансове право: проблеми утвердження та ефективного застосування. Публічне право. 2017. № 1. С. $10-17$.

8. Реверчук Н. Й., Дзямулич О. С. Сутність та необхідність управління репутацією суб'єктів підприємництва. Молодий вчений. 2015. № 4(2). С. 30-33.

9. Сербина О. Г., Пономар В. В. Тенденції розвитку мобільного банкінгу в Україні. Молодий вчений. 2014. № 3(06). С. 53-55.

10. Старостенко Г. Г., Сурженко А. В. Податкове регулювання банків в умовах становлення інформаційного суспільства. Ефективна економіка. 2013. № 11. [Електронний pecypc].

http://nbuv.gov.ua/UJRN/efek_2013_11_4

11. Зарубіжний досвід оподаткування фінансових установ та можливості його за- 
стосування в Україні [Електронний ресурс]. URL: http://gufer.net/podatkova/653/

12. Інформація про стан доходів і витрат банків / Офіційний сайт Міністерства Фінансів України [Електронний ресурс]. URL: https://www.minfin.gov.ua

13. Інформація про статистичну інформацію про діяльність банків / Офіційний сайт Державної служби статистики України. [Електронний ресурс]. URL: http://www.ukrstat.gov.ua/

14. Інформація про склад податків, що сплачуються банками / Офіційний сайт НБУ [Електронний ресурс]. URL: http://www.bank.gov.ua/control/uk/index.

15. Інформація про суму податку на прибуток, сплаченого банками/ Офіційний веб-сайт Державної податкової служби України [Електронний ресурс]. URL: http://www.sta.gov.ua/control/uk/index

\section{References}

1. «Principles of strategic reform of the public banking sector (strategic principles)» of August 20, 2020. Retrieved from: https://www.oschadbank.ua/sites/default/fi les/files/documents-2020.

2. Law of Ukraine "On Amendments to Articles 62 of the Law of Ukraine" On Banks and Banking "to ensure access of the central executive body implementing state tax policy to banking secrecy" of 08.09.2020 № 4073. Retrieved from: https://ips.ligazakon.net/document/GI03122A.

3. Danilov, O. D. Denisenko, D. E. (2014). Tendencies of capital taxation in Ukraine and the world. Business Inform, 3, 295-300.

4. Dyakonova, I., Mordan, E. (2015). Research of assessing the level of financial stability as a component of the mechanism of state regulation of the banking system. Business Inform, 1, 302-306.

5. Klyusko, L. A. (2018). Monetary regulation in conditions of macroeconomic instabil-

\footnotetext{
Стаття надійшла

до редакції : 05.05.2021 p.
}

ity. Collection of scientific works of the University of State Fiscal Service of Ukraine, 2, 107119.

6. Klyusko, L. A. (2019). Innovations in the field of banking. Collection of scientific works of the University of the State Fiscal Service of Ukraine, 2, 109-128.

7. Kovalchuk, A. T. (2017). Financial law: problems of approval and effective application. Public law, 1, 10-17.

8. Reverchuk, N. Y. Dzyamulych, O. S. (2015). The essence and necessity of managing the reputation of business entities. Young scientist, 4(2), 30-33.

9. Serbina, O. G., Ponomar, V. V. (2014). Tendencies of mobile banking development in Ukraine. Young scientist, № 3(06), 5355.

10. Starostenko, G. G., Surzhenko, A. V. (2013). Tax regulation of banks in terms of information society. Effective economy, 11. Retrieved from: http://nbuv.gov.ua/UJRN/efek_2013_11_4

11. Foreign experience of taxation of financial institutions and the possibility of its application in Ukraine. Retrieved from: http:// gufer.net/podatkova/

12. Information on the state of income and expenses of banks / Official site of the Ministry of Finance of Ukraine. Retrieved from: https://www.minfin.gov.ua

13. Information on statistical information on the activities of banks/ Official site of the State Statistics Service of Ukraine. Retrieved from: http://www.ukrstat.gov.ua/

14. Information about composition of taxes paid by banks / Official website of the NBU. Retrieved from: http://www.bank.gov.ua/control/uk/index.

15. Information on the amount of income tax paid by banks / Official website of the State Tax Service of Ukraine. Retrieved from: http://www.sta.gov.ua/control/uk/index

\footnotetext{
Стаття прийнята

до друку: 30.06.2021 p.
}

\section{Бібліографічний опис для цитування :}

Калінеску Т. В. Удосконалення обліку та оподаткування фінансово-кредитних установ / Т. В. Калінеску, Ю. Г. Перепелиця // Часопис економічних реформ. - 2021. - № 2(42). C. 32-38. 